\title{
Analysis of the Makran Coastline of Iran's Vulnerability to Global Sea-Level Rise
}

\author{
Ezatollah Ghanavati ${ }^{1, *}$, Majid Shah-Hosseini ${ }^{2}$ and Nick Marriner ${ }^{3}$ \\ 1 Department of Geomorphology, Faculty of Geographical Sciences, Kharazmi University, \\ Tehran 15719-14911, Iran \\ 2 Department of Geomorphology, Faculty of Human Sciences, Tarbiat Modares University, \\ Tehran 15719-14911, Iran; m.shahhosseini@modares.ac.ir \\ 3 CNRS, ThéMA, UMR 6049, MSHE Ledoux, Université de Franche-Comté, 32 rue Mégevand, \\ CEDEX, 25030 Besançon, France; nick.marriner@univ-fcomte.fr \\ * Correspondence: ghanavati@khu.ac.ir
}

Citation: Ghanavati, E.;

Shah-Hosseini, M.; Marriner, N Analysis of the Makran Coastline of Iran's Vulnerability to Global Sea-Level Rise. J. Mar. Sci. Eng. 2021, 9, 891. https://doi.org/10.3390/ jmse9080891

Academic Editor: Thomas Lippmann

Received: 30 June 2021

Accepted: 9 August 2021

Published: 18 August 2021

Publisher's Note: MDPI stays neutral with regard to jurisdictional claims in published maps and institutional affiliations.

Copyright: (C) 2021 by the authors Licensee MDPI, Basel, Switzerland. This article is an open access article distributed under the terms and conditions of the Creative Commons Attribution (CC BY) license (https:// creativecommons.org/licenses/by/ $4.0 /)$

\begin{abstract}
The SE coast of Iran is of great economic and environmental importance. Global climate change affects this coastline through sea level rise (SLR), compounded by a decrease in sediment budgets in coastal areas. This study developed a Coastal Vulnerability Index (CVI) for the SE coast of Iran using satellite, instrumental and field data. Eight risk variables were defined: coastal slope, regional coastal elevation, mean tidal range, mean significant wave height, rate of relative sea-level change, rate of shoreline change, environmental sensitivity and socio-economic sensitivity. The coast was divided into 27 segments based on geomorphic, environmental and socioeconomic traits. Coastal segments were categorized based on their vulnerability to each risk factor using a CVI. The resulting maps highlighted the vulnerability of each coastal segment to SLR. Approximately $50 \%$ of the coast is comprised of mostly rocky shores, which are less vulnerable to SLR. Approximately 33\% of the coastal length, including sandy beaches, tidal flats and mangrove forests, were determined to be highly vulnerable to SLR. Approximately $12 \%$ of the coastline was determined to be moderately vulnerable. Population centers and infrastructure were ranked as highly-to-moderately vulnerable to SLR. This study highlighted the high vulnerability of low-lying areas, such as lagoons and mangroves, in the western part of the Iranian coast of Makran. Proper coastal management and mitigation plans are essential in the future to protect coastal societies and environments.
\end{abstract}

Keywords: Makran coast; coastal vulnerability; sea-level rise; coastal vulnerability index; CVI; Gulf of Oman; Indian Ocean

\section{Introduction}

Coastal areas are dynamic and productive environments where continental and marine processes interact. Such areas are extremely sensitive to environmental changes. Mangrove forests, coral reefs, beaches and tidal flats are unique environments that host a plethora of endangered ecosystems. Coastal zones also have great economic significance due to their resources, recreational capacity and transport importance. Coastal landscapes are shaped by continuous processes and episodic high-energy events operating at diverse spatial and temporal timescales. Coastal environments and societies are extremely sensitive to natural hazards, especially in developing countries. Problems including coastal flooding, erosion and natural habitat loss have been compounded by human activities and global climate change [1-3]. Assessments of coastal vulnerability to hazards are complicated due to the great diversity of parameters and processes that interact in these areas [4,5]. Coastal erosion, the loss of natural habitats to sea level rise (SLR), storm surges and tsunamis are among the most important hazards threatening coastal zones.

Global SLR is a major consequence of climate change, resulting from the thermal expansion of seawater and the addition of ice-sheet meltwater to marine waterbodies. Even 
if global warming does not evolve to exceed present temperatures, sea levels will continue to rise during the 21st century [6]. In particular, SLR affects low-lying coasts and the human societies that occupy these areas. It is estimated that about $10 \%$ of the world's population live in low-lying coastal regions less than $10 \mathrm{~m}$ above sea level [7].

Based on the most recent greenhouse gas emission scenarios reported in their fifth assessment report, the Intergovernmental Panel on Climate Change (IPCC) predicts a global rise in sea level of $0.52-0.98 \mathrm{~m}$ by the end of 21st century. Under these scenarios, the viability of many coastal cities around the world will be threatened. Sea-level rise increases the vulnerability of coastal ecosystems and societies through an inundation of low-lying areas, increasing flood frequencies, coastal erosion and salt-water intrusion. In addition to SLR, an increase in sea surface temperatures is changing the frequency, intensity and spatial pattern of storms [8,9]. By the end of the 21st century, SLR could engender the displacement of millions of people, considerable damage to infrastructure and the loss of vast coastal ecosystems. In effect, SLR could lead to a loss of up to $22 \%$ of the world's coastal wetlands. In tandem with other human-induced habitat destruction, this figure could reach $70 \%$ of the world's coastal wetlands by the 2080s. Evaluating the vulnerability of a coast to SLR is key to an effective coastal zone management program. Coastal vulnerability is defined as the probability of socioeconomic and ecological systems being harmed by a hazardous event [10-12]. The IPCC defines vulnerability as the capacity of coastal zones to cope with the impacts of climate change and SLR. In order to quantify coastal vulnerability, coastal areas are classified based on their sensitivity to SLR. Various proxies have been developed to assess coastal vulnerability to SLR; these usually take into account a number of physical, environmental and socioeconomic factors. The Coastal Vulnerability Index (CVI) is a common and effective method for assessing the overall vulnerability of a coast. It was first designed to assess the impacts of SLR on coastal ecosystems in the U.S., Canada and Mexico [13]. This method has been followed and developed by numerous researchers to assess SLR-related hazards in many coastal areas of the world [14,15].

The coast of Makran is one of just a few coastlines in the world that experiences high rates of tectonic uplift and manifests interesting interactions between active sedimentation, erosion and tectonics [16]. This coast constitutes an interesting case study because of tectonic movements, the influence of the Indian Ocean monsoon, storm waves and its diverse coastal geomorphology. The coast hosts valuable and fragile ecosystems such as mangrove forests, coral reefs and lagoons. The sandy beaches host endangered species of sea turtle. Geopolitically, the Makran coast is also important for maritime transport from the Indian Ocean to central Asia. The coast is exposed to a variety of coastal hazards. Furthermore, the area is undergoing significant population growth and economic development due to the construction of new ports for international transport. The Makran coast is also of great environmental importance due to to its unique mangrove forests, tidal flats and sea-turtle habitats. The seaboard is an excellent example of an uplifting coast and is characterized by an alternation of uplifted rocky cliffs and low-lying bays [17,18]. The low-lying beaches and intertidal zone are prone to marine inundation and flash floods. Recent geological and geomorphological studies have shown that the region is seismically active and, during the Holocene, the coast has experienced catastrophic coastal inundation due to tsunamis. The last and only recorded tsunami happened after an $8^{+}$magnitude earthquake off the coast of Pasni in Pakistan, but historical and geomorphological evidence attest to the periodic impact of extreme waves [19]. Exceptional storms are mainly related to Arabian Sea tropical cyclones. In recent decades, tropical cyclones have affected the coast of Makran more frequently. For instance, Cyclone Gonu, in June 2007, was an unprecedented event that drastically impacted the region $[20,21]$.

So far, few studies have focused on SLR-related hazards on the Iranian coast of the Persian Gulf and the Gulf of Oman. Goharnejad et al. [22] proposed a methodology for projecting climate change impacts on sea level rise on the southern coast of Iran. Using numerical models, they predicted an average SLR of $0.33-0.59 \mathrm{~m}$ for 21 st century under different climate-change scenarios. Mafi-Gholami et al. [23] applied a modified CVI method 
to assess the vulnerability of the northern coasts of the Persian Gulf and the Gulf of Oman in the Hormozgan province of Iran. Hadipour et al. [24] introduced a social vulnerability index (SoVI) in order to evaluate social vulnerability to SLR in the Bandar-Abbas port on the northern coast of the Strait of Hormoz.

In this study, we probed the vulnerability of Iran's Makran coast to SLR along the northern coast of the Gulf of Oman, from the Iran-Pakistan border to the Strait of Hormoz between the Gulf of Oman and the Persian Gulf. Due to the great diversity of the Makran's coastal landforms and environments, the coast was divided into 27 segments. The overall vulnerability of each coastal segment was evaluated using a CVI that could assist decision makers and inhabitants as they plan for and combat future hazards. Makran is an excellent example of an uplifting coast, with unique geomorphological and geological features. Within this context, our study aimed to furnish a better understanding of the impact of SLR on uplifting coasts on both the regional and global scales.

\section{The Study Area}

Makran is the historical name for the northern coast of the Gulf of Oman in the northwestern Indian Ocean. The coast stretches for $1000 \mathrm{~km}$, from the Strait of Hormoz in the south of Iran to near Karachi in Pakistan (Figure 1). The western portion of the coast is in Iran, while the eastern part lies in Pakistan. In Iran, the main port and population center is Chabahar, which hosts approximately 120,000 inhabitants. Karachi is the main coastal city in Pakistan with a population exceeding 16 million. At the time of this study, a development program is underway in Chabahar's port that aims to upgrade it to an international hub for maritime transport between central Asia and the Indian Ocean.The geology of Makran is characterized by an active margin formed by subduction of the Arabian Plate beneath the Eurasian Plate along the Makran subduction zone. The convergence rate along the subduction zone varies between $2.3 \mathrm{~cm} / \mathrm{y}$ at the western end and $2.9 \mathrm{~cm} / \mathrm{y}$ on the eastern margin $[25,26]$. Coastal uplift is highly variable along the coast and, in the study area, Holocene coastal uplift ranges between 1 and $6 \mathrm{~mm} / \mathrm{y}$. This difference could be related to the variable nature of uplift according to fault-bonded coastal blocks [27]. Shah-Hosseini et al. [28] studied a strandplain rimming Chabahar Bay and suggested an uplift rate of 1 to $2 \mathrm{~mm} / \mathrm{y}$ for this portion of the coastline. More recently, Normand et al. [16] dated a number of uplifted marine terraces along the coast using optically stimulated luminescence (OSL), reporting uplift rates of $0.05-1.5 \mathrm{~mm} / \mathrm{y}$, with an exceptionally high rate of $5 \mathrm{~mm} / \mathrm{y}$ on the eastern part of the coast. An uplift rate of $1-2 \mathrm{~mm} / \mathrm{y}$ is generally accepted as being the mean value. The Makran coast is bounded by the Makran range to the north (Figure 1). Conjugate sets of normal faults, trending in a NE-SW and a NW-SE direction, are frequent in Quaternary sediments. The continental shelf is 10 to $40 \mathrm{~km}$ wide and attains a depth of nearly $100 \mathrm{~m}$ below sea level [29,30]. The Makran subduction zone is a major seismic source in the Indian Ocean and has caused numerous earthquakes in the past. Some large earthquakes have triggered tsunamis. The last event was the earthquake and tsunami of 1945, which caused heavy damage and loss of life on the coasts of Pakistan, Iran and Oman. A similar tsunami today would cause much greater damage and loss of life [31,32].

Marine terraces, headlands and arcuate bays are characteristic landforms of coastal Makran (Figure 2). Omega-shaped and arcuate bays such as Tang, Pozm, Chabahar, and Guwader are partially protected from storms and large waves by flanking rocky headlands. The interior of the bays mainly consist of sandy and gravelly beaches. Strandplains are particularly well developed in protected bays as a result of coastal progradation since the mid-Holocene. Elevated marine terraces extend for tens of kilometers inland creating a step-like morphology. Uplifted Pliocene-Pleistocene marine marls and sandstones are continually undergoing intensive erosion, forming a rough geomorphology. Elevated platforms with deep incisions (Figure 3a), sandy beaches (Figure 3b), tidal flats (Figure 3c), mangroves and foredunes (Figure 3e) are important geomorphological features. Ports and infrastructure (Figure 3d) are developed in low-lying areas inside Chabahar bay. The Iranian coast of Makran is a subtropical and arid region. Mean annual rainfall is less than $100 \mathrm{~mm}$ and 
precipitation is extremely variable. The climate in the Gulf of Oman is mediated by the Indian Ocean monsoon system, which causes marked seasonal productivity and variability in sediment input $[33,34]$. On the Iranian coast, the winter (NE) monsoon, with moderate winds, begins in October and reaches its maximum intensity in December and January. The summer (SW) monsoon is longer and more intense; it begins in April and attains its maximum strength from June to September. Tropical storms and cyclones occasionally form in the Arabian Sea during May to June but rarely reach the coast of Makran. Cyclone Gonu (category 5) occurred in June 2007 and was the most intense tropical storm recorded in the Gulf of Oman. On the Iranian coast, significant wave heights of $\sim 4.5 \mathrm{~m}$ were recorded off the port of Chabahar.

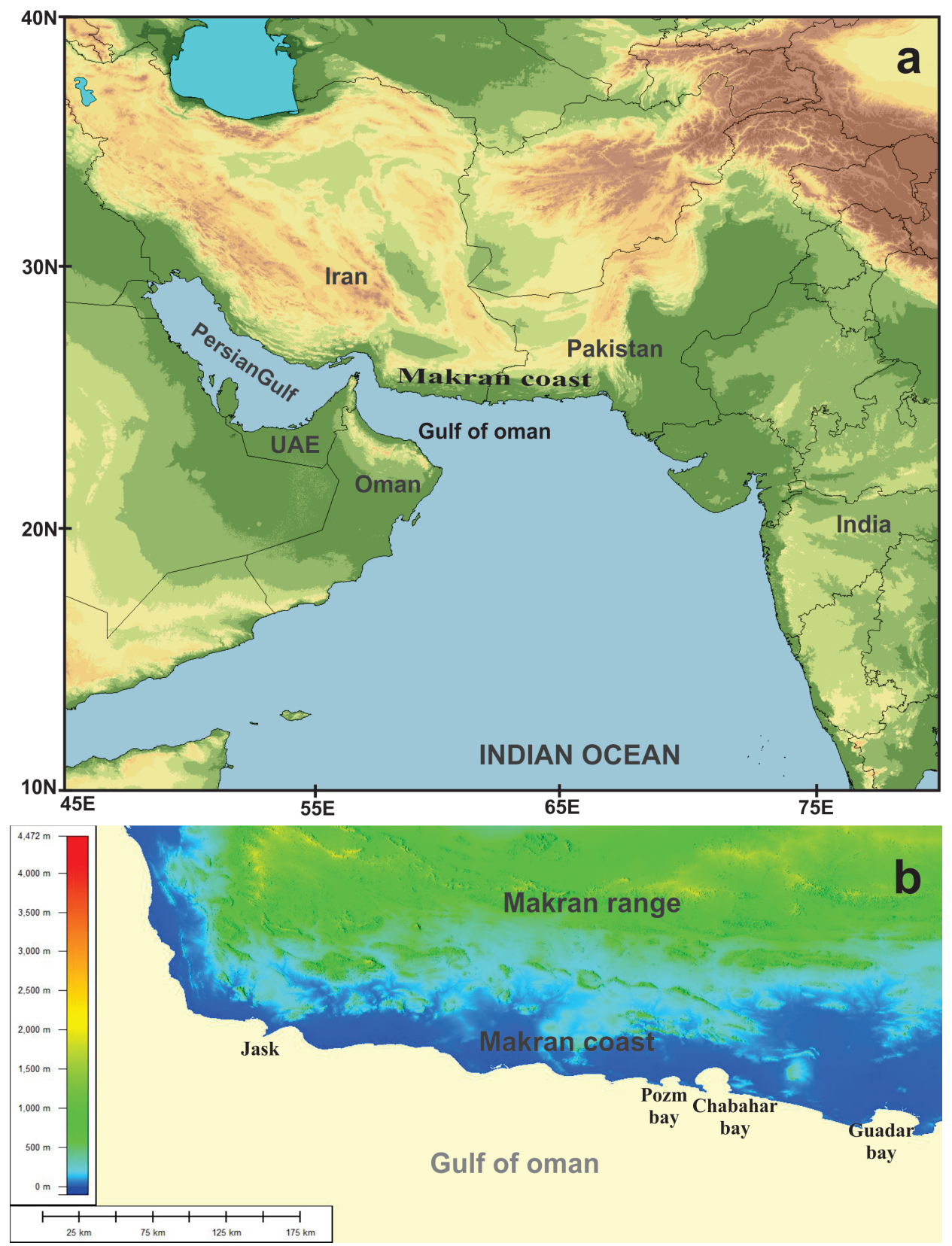

Figure 1. Location map of the Makran coast in the northwestern Indian Ocean (a) SRTM-DEM of the Iranian coast of Makran (b). 


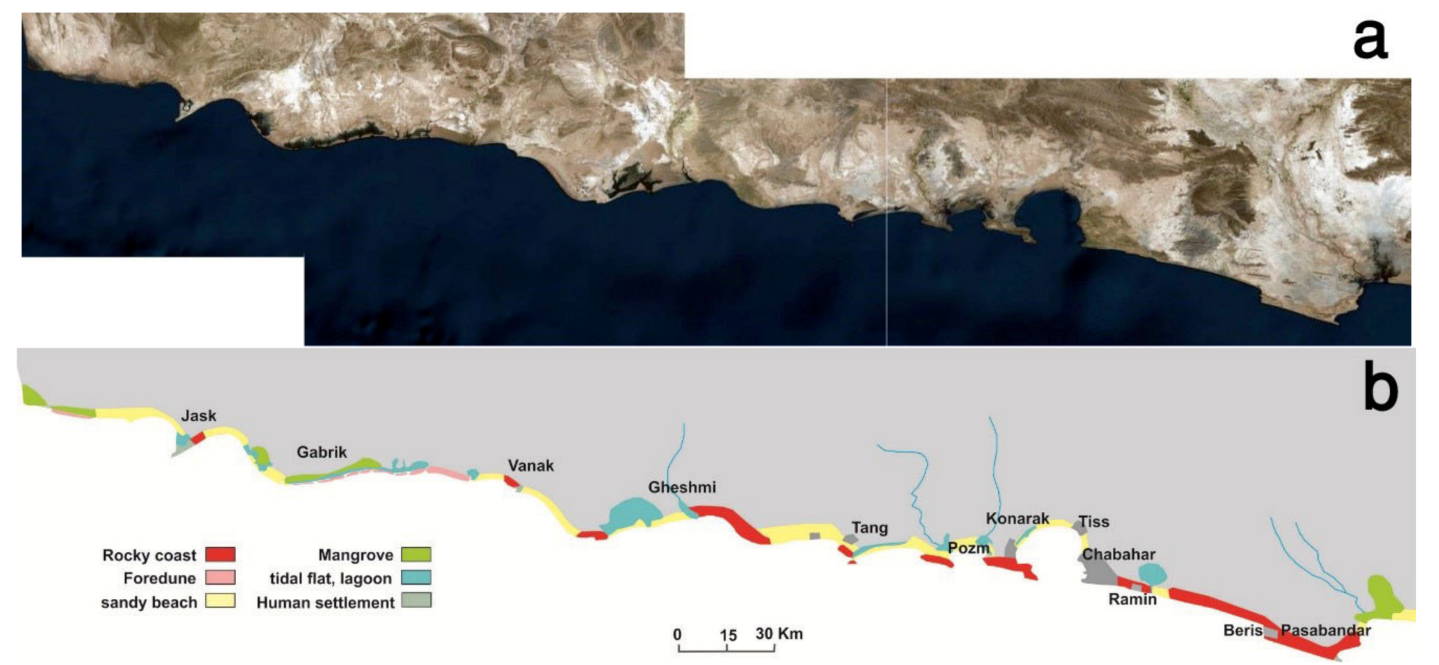

Figure 2. Landsat-8 image (a) and main geomorphological features and population centers of the Iranian coast of Makran (b).
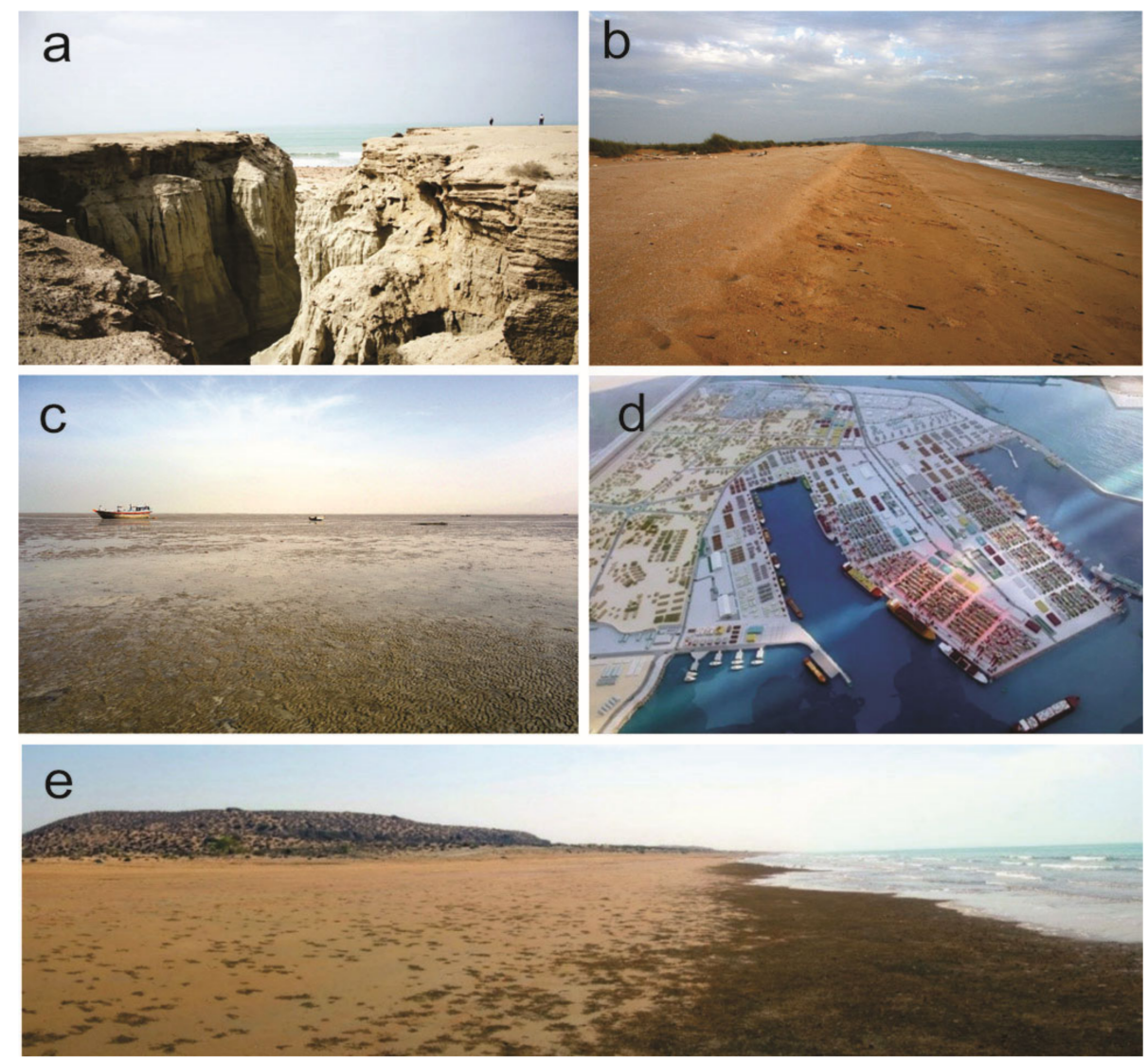

Figure 3. Some characteristic geomorphological features of the Iranian coast of Makran. (a) Uplifted marl and sand formations undergoing intensive erosion. (b) Sandy beach. (c) Tidal flat. (d) Man-made coast. (e) Coastal sand dunes.

\section{Methods}

A number of semi-quantitative and quantitative approaches have been developed to evaluate coastal vulnerability. One of the most commonly used metrics is the Coastal Vulnerability Index (CVI), which was first developed to assess coastal vulnerability to inundation and erosion related to global SLR. The Coastal Sensitivity Index (CSI) is another 
method but, unlike the CVI, CSI only evaluates physical aspects of the coast and ignores socioeconomic variables. The CVI approach developed by Gornitz [13] has been widely applied in coastal vulnerability assessments around the world and been adapted to diverse coastal settings [35]. In the original database, Gornitz used eight risk variables: coastal geomorphology, regional coastal slope, relative sea level change, mean significant wave height, historical shoreline change rate and mean tidal range. Later, the method was modified by adding climatological variables to include the impact of severe storms on coastal vulnerability.

\subsection{Calculation}

In this study, we followed the methodology introduced by Thieler and HammerKlose [36,37], with modifications in accordance with the study site. We used eight risk variables to calculate the CVI: (1) coastal slope, (2) regional coastal elevation, (3) mean tidal range, (4) mean significant wave height, (5) rate of shoreline change (erosion and progradation), (6) rate of relative sea level changes, (7) socio-economic sensitivity and (8) geomorphological and environmental sensitivity (Table 1). Due to the limitations of available databases, extensive fieldwork was organized along the Makran coast in March 2017 in order to complete data using direct observations.

Table 1. Risk variables and data sources used to calculate the Coastal Vulnerability Index.

\begin{tabular}{ccc}
\hline Risk Variable & Source of Data & Period \\
\hline Coastal slope & Coastal profiles from Iran's integrated coastal zone management. & 2014 \\
Coastal elevation & SRTM-DEM (90 m) & 2018 \\
Tidal range & Iran's ports and maritime organization data center & 2018 \\
Mean significant wave height & Iran's ports and maritime organization data center & 2018 \\
Shoreline change & Landsat-8 (2017), Landsat-5 (1987) & $1987-2017$ \\
Relative sea level changes & Indian Ocean tide gauge stations, TOPEX/Poseidon satellite altimeter & Since 1950 \\
Geomorphology and environment & Landsat-8, field observations & 2018 \\
Population density & National statistical center of Iran & 2017 \\
\hline
\end{tabular}

\subsubsection{Coastal Slope}

Near-shore bathymetry is the baseline for essential hydrodynamic processes. Coastal inundation is strongly related to coastal slope. Shorelines with gentle slopes are more prone to flooding from SLR, storm surges and even tsunami events. Even a slight rise in sea level can cause inundation of vast coastal zones, in contrast to areas with steeper slopes-which are consequently given a low risk rating. The coastal slope was estimated using coastal profiles from Iran's Integrated Coastal Zone Management (ICZM) report [38]. These shore-normal profiles were extracted from high-resolution hydrographic maps (1:500) and combined with field measurements. The profiles were $20 \mathrm{~km}$ long. The landward limit of the profiles was the upper extent of the active beach or foot of the rocky cliff (backshore zone). The submerged extent depth was variable and mostly covered the continental shelf. In total, 210 profiles were used to determine coastal slopes in this study.

\subsubsection{Regional Coastal Elevation}

Regional coastal elevation refers to the mean elevation of a particular coastal segment from mean sea level. It provides an estimate for the extent of the emerged part of the coastal zone threatened by SLR as well as the sensitivity of the coast to flooding during a storm surge or tsunami. High elevation coastal areas are considered less vulnerable and vice versa. The mean elevation for each coastal segment was estimated using altimetry data obtained from the Shuttle Radar Topography Mission (SRTM-2017) To calculate the mean elevation for each coastal segment, a coastal band of $\sim 1 \mathrm{~km}$ was buffered and selected in ArcGIS software 10.5.1 (2017-06-29). The average height value of this segment was considered to be the regional coastal elevation for the segment. 


\subsubsection{Mean Tidal Range}

Tidal range is defined as the vertical difference between the highest high tide and the lowest low tide. Tidal range mediates inundation hazards. Some previous studies have considered coasts with wide tidal ranges to be highly vulnerable because a large tidal range is associated with strong tidal currents that could transport unconsolidated sediments away from the coast. Other studies assumed that coastal settings with a low tidal range were the most vulnerable [39-41]. These studies argued that a large tidal range increases the resilience of a coastal area to SLR and that coastal areas with a low tidal range have a greater likelihood of being flooded by high-tide storms and are therefore at greater risk of erosion and flooding. We considered the first premise to be more compatible with our present study. On the Makran coast, vast tidal flats and channels, in addition to the high erodibility of soft sediments, tend to accentuate erosion and sediment transport. Hence, a macro-tidal coast where the tidal range is greater than $4 \mathrm{~m}$ is most vulnerable and a micro-tidal coast is least vulnerable. The tidal ranges were obtained from the database of Iran's ports and maritime organization data center. The tidal range varied along the coast and increased toward the west. At the eastern end, the range was close to $2 \mathrm{~m}$, reaching 3.5 $\mathrm{m}$ close to the Strait of Hormoz. Hence, the coast was determined to be meso-tidal at all studied segments.

\subsubsection{Significant Wave Height}

The significant wave height denotes the wave energy or the ability of waves to mobilize and transport coastal sediments. It is calculated by averaging the height of one-third of the highest waves during a given time period. Most CVI studies use the mean annual significant wave height to evaluate the vulnerability of a coast. Lopez et al. [42] added a power metric to this variable to accommodate for the impact of storm conditions on the coast. The significant wave height for the study area was obtained from the wave database of Iran's ports and maritime organization data center. Wave heights fluctuate seasonally, mainly in relation to the Indian Ocean monsoon. The strongest waves occur from June to August, with significant wave heights of 1 to $3 \mathrm{~m}$ and wave periods between 4 and $8 \mathrm{~s}$ [43]. To cover the wave conditions of the entire study area, we used the annual mean significant wave height $(1.25 \mathrm{~m})$, which fell into the moderate range.

\subsubsection{Shoreline Change}

Shorelines are in constant mutation due to sediment accretion, erosion, tidal processes and sea-level changes. Shoreline changes may occur due to both man-made and natural processes. They can be used as an indicator of SLR, as well as human-induced changes in the coastal zone. We used Landsat-MSS (year 1987), Landsat-TM (year 1997) and Landsat-ETM (year 2017) satellite images to investigate shoreline changes over a 30-year period. Raw images were processed using the ERDAS Imagine 9.2 software (2017-07-15). Image processing included image enhancement, geo-referencing and band extraction. For each year, the shorelines were digitized and superimposed using ArcGIS version 10.3. The shift in shoreline position between 1987 and 2017 was used to calculate the rate of shoreline change.

\subsubsection{Rate of Relative Sea Level Changes}

Land masses may move vertically due to uplift or subsidence. Relative sea level change is the sum of vertical land movements and eustatic sea level rise. In the Indian Ocean, a combination of historical records from tide gauges and sea level data from the TOPEX/Poseidon satellite altimeter yielded an average eustatic SLR of $\sim 2.0 \mathrm{~mm} / \mathrm{y}$ for the period 1950-2001 [44]. SLR estimates using satellite altimeter data attested to a mean global SLR rate of $\sim 3 \mathrm{~mm} / \mathrm{y}$ since 1993 [45]. Based on SLR projections, global SLR is predicted to accelerate in the 21st century. Even at a low-emission scenario, the rate of SLR is estimated to be above $3 \mathrm{~mm} / \mathrm{y}$; this rate could exceed $20 \mathrm{~mm} / \mathrm{y}$ in worst-case scenarios [46,47]. 
Because the coast of Makran is uplifting due to tectonic activity, the effective rate of SLR is estimated by subtracting the mean rate of uplift rate from mean eustatic SLR.

\subsubsection{Socioeconomic Variables}

Population density and coastal infrastructure are major socioeconomic variables influencing the vulnerability of a coast to SLR. Coastal areas with high population densities are considered to be highly vulnerable because more people are exposed to coastal hazards for a given area. Human populations and infrastructure can also put pressure on the coastal environments and resources. In this study, population densities were calculated using data from the National Statistical Center of Iran. Urban areas and infrastructure densities were calculated using recent Landsat-8 Satellite images.

\subsubsection{Geomorphological and Environmental Sensitivity}

Sea level rise threatens coastal ecosystems and landforms by direct inundation, sedimentation or erosion and increased salinity in lagoons and estuaries. Coastal landforms and environments respond differently to sea level rise. Rocky cliffs and headlands are less sensitive while low-lying clastic landforms, such as mudflats, are extremely vulnerable. Under rising sea level conditions, the intertidal zone may migrate landwards where, restricted by topography or human activities, intertidal environments are particularly vulnerable [48] In this study, six main coastal types were recognized (Figure 2). Headlands and rocky coasts composed of consolidated materials such as sandstone were determined to be less vulnerable to sea level rise, while clastic coasts such as lagoons, intertidal wetlands and mangroves showed the highest vulnerability (Table 2).

Table 2. Ranking of risk variables.

\begin{tabular}{|c|c|c|c|c|c|}
\hline Risk Variable & Very Low (1) & Low (2) & $\begin{array}{l}\text { Stal Vulnerability I } \\
\text { Moderate (3) }\end{array}$ & High (4) & Very High (5) \\
\hline Coastal slope $(\%)$ & $>1.2$ & 0.9 to 1.2 & 0.6 to 0.9 & 0.3 to 0.6 & $<0.3$ \\
\hline $\begin{array}{l}\text { Regional Coastal } \\
\text { Elevation }(\mathrm{m})\end{array}$ & $>10$ & 10 to 7 & 7 to 4 & 4 to 1 & $<1$ \\
\hline $\begin{array}{c}\text { Mean tide range } \\
(\mathrm{m})\end{array}$ & $>1$ & 1 to 2 & 2.0 to 4.0 & 4.0 to 6.0 & $>6$ \\
\hline $\begin{array}{l}\text { Mean significant } \\
\text { wave height }(\mathrm{m})\end{array}$ & $<0.5$ & 0.5 to 1 & 1 to 2 & 2 to 3 & $>3$ \\
\hline $\begin{array}{l}\text { Shoreline change } \\
\qquad \begin{array}{l}(\mathrm{m} / \mathrm{y})+ \\
\text { (accretion)- } \\
\text { (retraction) }\end{array}\end{array}$ & $>1$ & 1 to 0.5 & 0.5 to 0 & 0 to -0.5 & $<-1$ \\
\hline $\begin{array}{l}\text { Relative sea level } \\
\text { changes }(\mathrm{mm} / \mathrm{y})\end{array}$ & $\leq 0$ & 0 to 3 & 3 to 6 & 6 to 9 & $>9$ \\
\hline $\begin{array}{c}\text { Socioeconomic } \\
\text { factors } \\
\text { Population Density } \\
\text { (people } / \mathrm{Km}^{2} \text { ) }\end{array}$ & $\begin{array}{c}\mathrm{PD} \leq 1500 \\
\text { No infrastructure }\end{array}$ & $\begin{array}{l}\text { PD 1500-3000 } \\
\text { Small fishing } \\
\text { harbor }\end{array}$ & $\begin{array}{l}\text { PD 3000-4500 } \\
\text { Medium fishing } \\
\text { harbor }\end{array}$ & $\begin{array}{l}\text { PD 4500-6000 } \\
\text { Town/small port }\end{array}$ & $\begin{array}{l}\mathrm{PD} \geq 6000 \\
\text { Main port }\end{array}$ \\
\hline $\begin{array}{l}\text { Geomorphological } \\
\text { and environmental } \\
\text { sensibility }\end{array}$ & $\begin{array}{l}\text { Rocky coasts } \\
\text { above } 10 \mathrm{~m}\end{array}$ & $\begin{array}{c}\text { Rocky coast } 3 \text { to } \\
10 \mathrm{~m}\end{array}$ & $\begin{array}{c}\text { Foredune higher } \\
\text { than } 3 \mathrm{~m}\end{array}$ & Beaches & $\begin{array}{c}\text { Tidal flats, } \\
\text { mangroves, lagoon }\end{array}$ \\
\hline
\end{tabular}

\subsection{Risk Ranking}

There are different ways to rank risk variables in a CVI. Most studies have followed the USGS ranking procedure [49]. This method ranks each variable on a scale of 1 to 5 , where 1 denotes the lowest vulnerability and 5 the highest. This study used the same ranking system (Table 2). 


\subsection{Calculation of the CVI}

The studied coast was divided into 27 sections based on physical, environmental and socioeconomic traits. For each variable, a risk rating was given to each sector (Table 2). Subsequently, the CVI was calculated according to the formula of Gornitz:

$$
\mathrm{CVI}=\sqrt{ }(\text { a.b.c.d.e.f.g.h }) / 8
$$

Where a to $h$ are the ranks given to eight risk variables present in Table 2. As commonly used in past studies, equal weight was assigned to all variables [50,51]. CVI values have also been categorized into five classes: very high, high, moderate, low and very low.

\section{Results}

\subsection{Coastal Slope}

Based on 210 coastal profiles, the coastal slope ranged between $0.12 \%$ and $1.15 \%$. Figure 4 shows the vulnerability classes of the coast in relation to coastal slope. For the rocky coasts, the slope ranged between $0.6 \%$ to $1.15 \%$ and fell into the low vulnerability category. For low-lying coasts, the slope ranged between $0.12 \%$ and $0.6 \%$, which is moderately to highly vulnerable to SLR.Low-lying coastal settings are more frequent on the western half of the coast. Where vast tidal flats and mangroves extend east of Gabrik and west of Jask (Figure 4).

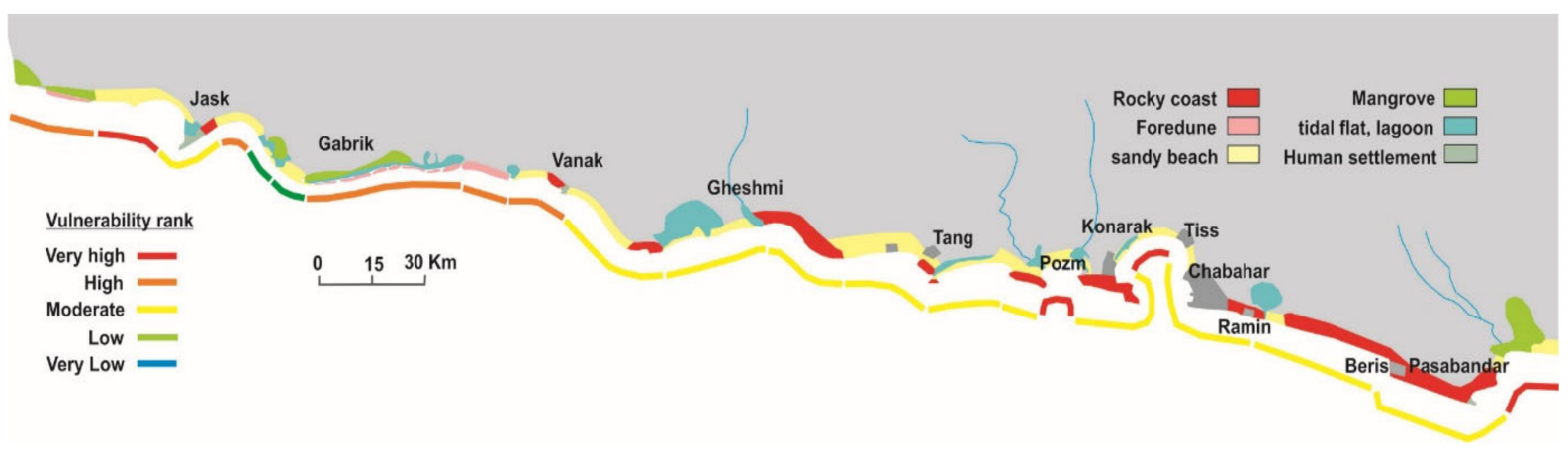

Figure 4. Risk rating of the Iranian coast of Makran based on the coastal slope.

\subsection{Coastal Elevation}

Based on topographic maps and SRTM-DEM data, elevation on the Iranian coast of Makran ranged between 0 and $687 \mathrm{~m}$. The highest cliffs lay east of Beris (Figure 1). The mean elevation of each coastal segment was calculated by averaging the surface elevation of each coastal segment and the vulnerability of each was ranked from very low to high (Figure 5). Rocky coasts were mainly classified as very low or low. Beaches fell into the moderate vulnerability category. Low-lying coasts, such as mangroves, tidal flats and lagoons were found to be highly vulnerable to SLR or extreme waves. However, in natural conditions, the presence of sand spits and foredunes up to $14 \mathrm{~m}$ above mean sea level between Gabrik and Vanak, could potentially protect the coast from the impact of large waves.

\subsection{Mean Tidal Range}

Two tide-gauge stations operated by Iran's ports and maritime organization at Jask and Chabahar are present in the study area. At Chabahar port, the monthly tidal range is between 1.2 to $2.8 \mathrm{~m}$. At Jask port, at the western end of the studied coast, the tidal range is between 1.5 to $3 \mathrm{~m}$. In general, the tidal range increases slightly towards the west, but for the whole Iranian coast of Makran, the mean tidal range is between 2 and $3 \mathrm{~m}$. The coast is meso-tidal and thus fell into the moderate vulnerability category (Table 2). 


\subsection{Mean Significant Wave Height}

Wave data were based on records from a Chabahar buoy located near the port of Chabahar at a water depth of $17 \mathrm{~m}$. Significant wave height and directions showed marked temporal variations, with maximum wave heights from July to August in accordance with the Indian Ocean summer monsoon. The dominant direction during this period is SE, and significant wave heights may exceed $3 \mathrm{~m}$. From January to May, the dominant direction is SW and significant wave heights fall mostly between 0.5 and $2 \mathrm{~m}$, but may occasionally exceed $3 \mathrm{~m}$. September to December is the calmest period and significant wave heights rarely exceed $2 \mathrm{~m}$. The mean significant wave height exceeds $1.25 \mathrm{~m}$ during the summer monsoon. The wave heights decrease marginally toward the west but are mostly above $1 \mathrm{~m}$. Thus, mean significant wave height for the study area fell into the moderate risk category (Table 2).

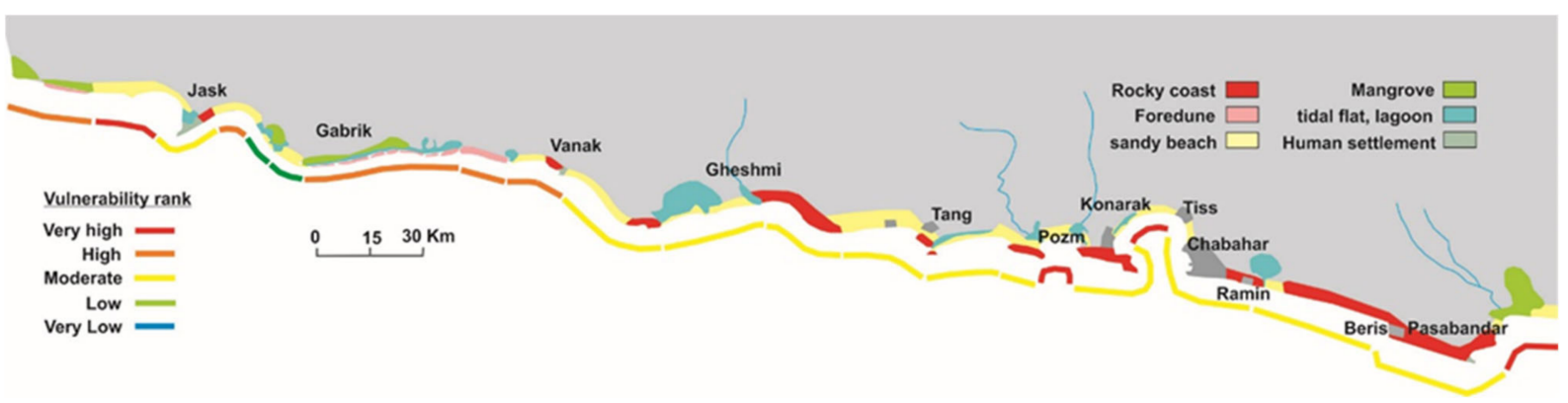

Figure 5. Risk rating of the Iranian coast of Makran based on coastal elevation.

\subsection{Rate of Shoreline Change}

The rate of shoreline change was calculated between 1987 and 2017 based on Landsat 5 and 8 satellite images taken during similar tide conditions (Figure 6). For the major part of the studied coast, shoreline change was not significant.

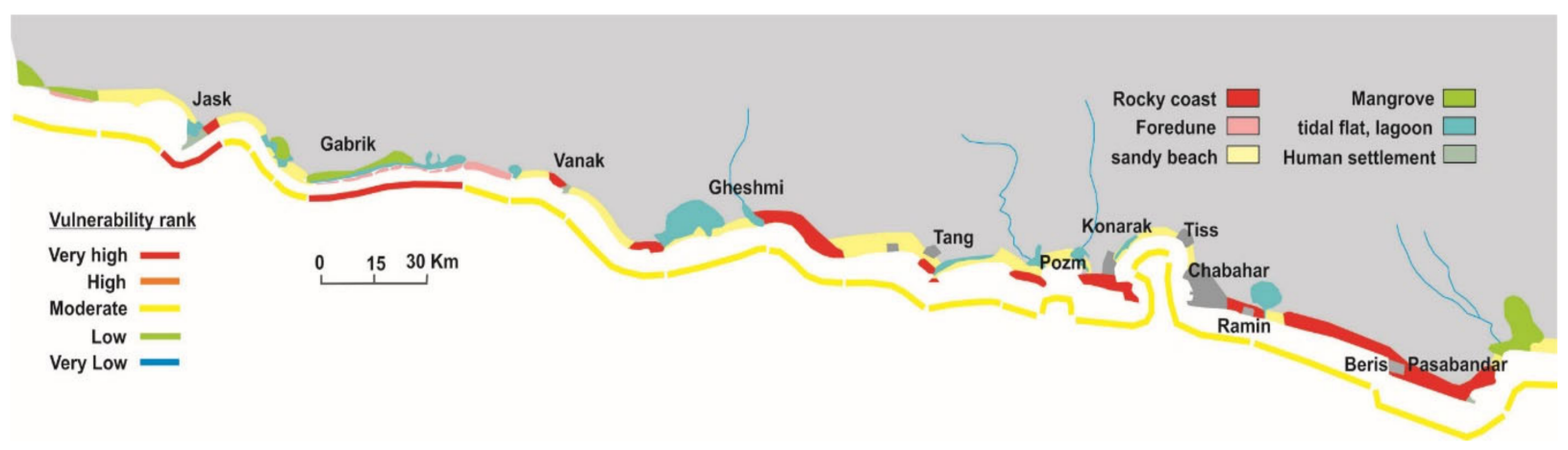

Figure 6. Risk rating of the Iranian coast of Makran based on shoreline changes between 1987 and 2017.

Nonetheless, a high rate of shoreline change was observed in two coastal areas. East of Jask, the shoreline between two sea walls retreated by about $72 \mathrm{~m}$ since 1987 . This erosion is essentially related to a fall in sediment supply by longshore currents as a consequence of coastal infrastructure development to the west. At Gabrik, a sand spit about $4 \mathrm{~km}$ long and $200 \mathrm{~m}$ wide has been significantly eroded since the construction of breakwater and channels related to a shrimp farm (Figure 7). This could potentially increase the vulnerability of this section of the coast to inundation and storm surges. Considering the spatial resolution of Landsat images, minor shoreline changes are difficult to detect. However, field observations and interviews with local inhabitants did not attest to any significant shoreline change in recent decades. 


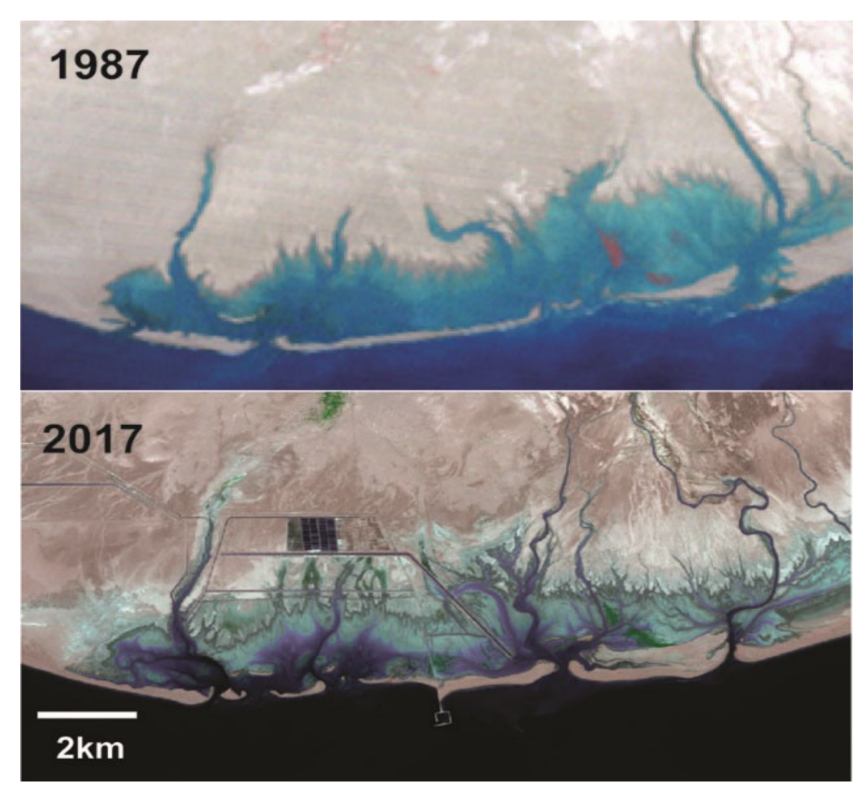

Figure 7. An example of shoreline change as a result of human activity at Gabrik, after construction of a jetty in the middle part of the photo, the sandy barriers on the left side are eroded while sand spits and barriers on the right side have expanded.

\subsection{Relative Sea Level Change}

As outlined above, the coast of Makran is uplifting due to active tectonics. Relative sea level change is estimated as being the difference between eustatic sea level rise and tectonic uplift. Satellite altimetry radar data from the National Oceanic and Atmospheric Administration (NOAA) and TOPEX/Poseidon recorded an SLR of $3.2 \mathrm{~mm} / \mathrm{y}$ for the coast of Makran since 1993 (data available online). Even under low-emission SLR projections, sea level rise rate will be over $5 \mathrm{~mm} / \mathrm{y}$ for the rest of the 21st century. For this study, we considered an average SLR rate of $4 \mathrm{~mm} / \mathrm{y}$ for the 21st century as a minimum value. Determination of a mean uplift rate was inherently complicated due to the complex morphodynamics of the Makran coast. Fault-bounded blocks may be subjected to variable uplift. Rates of 0.05 to $6 \mathrm{~mm} / \mathrm{y}$ were reported in different studies. The most recent OSL dating of uplifted marine terraces along different parts of the coast suggested uplift rates of 0.05 to $1.5 \mathrm{~mm} / \mathrm{y}$. Radiocarbon dating of marine shells from Holocene beach ridges around Chabahar Bay suggested uplift rates of 1 to $2 \mathrm{~mm} / \mathrm{y}$ [52]. For this study, we considered an average rate of coastal uplift between 1 and $2 \mathrm{~mm} / \mathrm{y}$ based on previous studies. Therefore, we estimated an average relative SLR rate of $2-3 \mathrm{~mm} / \mathrm{y}$ for the Makran coast. This range fell into the low risk category (Table 2).

\subsection{Geomorphological and Environmental Sensitivity}

Based on Landsat-8 satellite images and field observations, the study area was divided into six coastal types according to physical, geomorphological and environmental traits. Identified coastal types included: (1) rocky coasts, (2) sandy shorelines (foredunes), (3) sandy beaches, (4) mangroves, (5) tidal flats and lagoons and (6) human settlements. The rocky shoreline comprises uplifted Pleistocene sandstones and mudstones. The elevation of cliffs generally increases towards the east and exceeds $60 \mathrm{~m}$ east of Beris. In total, $\sim 157 \mathrm{~km}$ of the seaboard is rocky coast ( $29 \%$ of the total). Sandy beaches are mainly inside arcuate bays where the coast is protected by rocky headlands. Beach-ridge successions in these bays are related to the Holocene transgression. Sandy beaches are $132 \mathrm{~km}$ long in total, or $\sim 24.5 \%$ of the total coastal length. Vast tidal flats and lagoons are mainly found in low-lying coastal setting and estuaries. Coastal lagoons are usually protected by sand spits or barrier islands and are connected to a network of tidal channels and creeks. Although muddy tidal flats cover vast coastal areas, their extent along the coastline is limited to 
$\sim 133 \mathrm{~km}$, the equivalent of $24 \%$ of the studied coastline. Mangroves are important coastal ecosystems on the Makran coast, and are found in the intertidal zone along protected coasts or tidal creeks. Mangroves comprise $\sim 29 \mathrm{~km}(5.4 \%)$ of the coastline. Human settlements and infrastructure in total extend for $\sim 63 \mathrm{~km}$ along the coast, equivalent to $11.7 \%$ of the entire coastline. Coastal types were defined on the basis of their sensitivity to SLR. Rocky coasts showed low levels of vulnerability due to their high topographic elevation and their resistant basement geology. Foredunes and sandy beaches were considered to be moderately to highly vulnerable, while low-lying areas such as mangroves, lagoons and tidal flats were determined to be inherently very vulnerable to SLR (Figure 8).

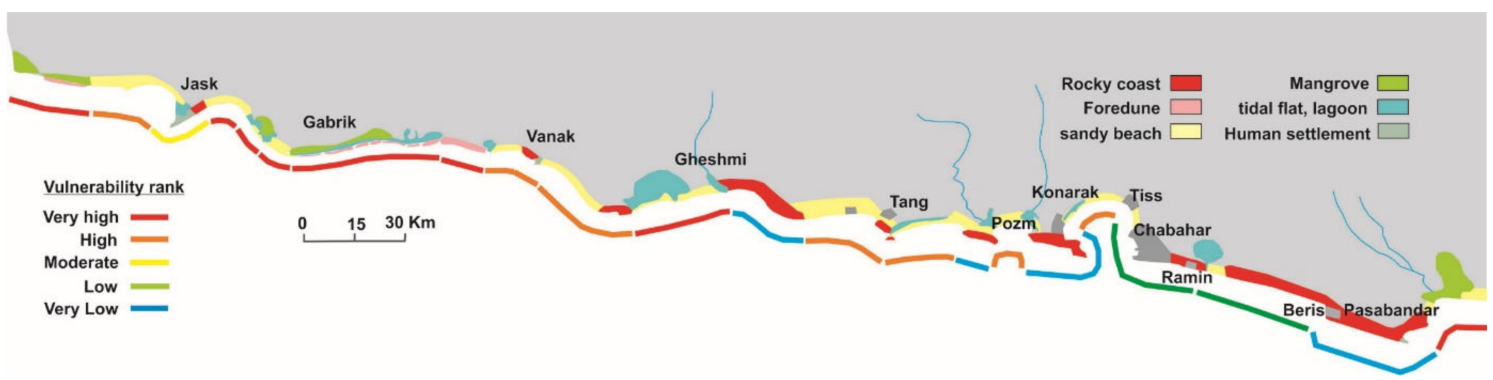

Figure 8. Risk rating of the Iranian coast of Makran based on geomorphology and environmental sensitivity.

\subsection{Socioeconomic Risk}

Human settlements along the coast were divided into two categories: (1) local inhabitants, who mainly live in small coastal villages around the headlands of protected bays and whose livelihood is mostly based on traditional fishing; and (2) ports and infrastructures, which are mostly geared towards international shipping. Modern infrastructure is concentrated around Jask and the Chabahar Bay where a free trade zone is developing. Chabahar and Jask are also key population centers. According to the latest figures from the Statistical Center of Iran, the population of Chabahar is over 120,000 and its population density is 6000 People $/ \mathrm{km}^{2}$. The population of Jask is 95,000 for an area of approximately $15 \mathrm{~km}^{2}$. These two ports were classified as very highly vulnerable to SLR and its consequences. Smaller population centers such as Vanak, Tang, Beris and Pasbandar have lower population densities and their economies are mainly dependent on traditional fishing and trading. These areas were classified as highly vulnerable (Figure 9).

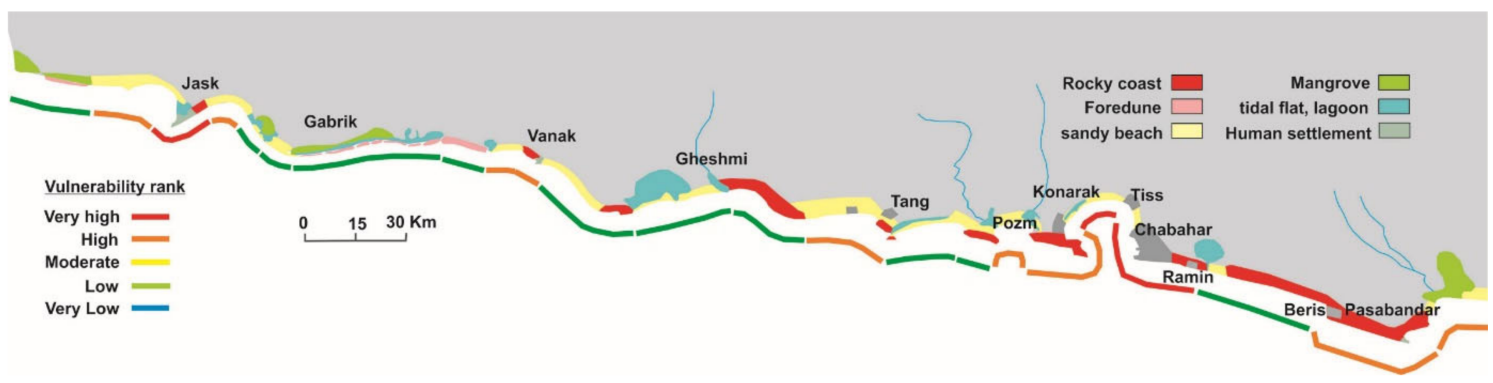

Figure 9. Risk rating of the Iranian coast of Makran based on socioeconomic factors.

\subsection{Overall Vulnerability of the Coast}

The overall vulnerability of the coast to SLR was evaluated based on the sensitivity of the coast to eight physical and socioeconomic parameters. Relative rankings and vulnerability to each variable of 27 coastal segments of the Iranian coast of Makran are presented in Table 3. The calculated CVIs varied between 6.4 and 52. The CVI was categorized into 5 ranks, as presented in Table 4 . The vulnerability of 27 coastal segments is illustrated in Figure 10. Rocky cliffs and headlands showed low vulnerability to SLR. Sandy beaches and coastal dunes generally fell into the moderate or high risk categories (Figure 10). Tidal 
flats, lagoons and mangroves were in the high and very high vulnerability classes. Because the physical risk variables - such as mean tidal range, significant wave height and relative sea level rise range-showed constant values across the study area, the variations in the vulnerability of the 27 coastal sections were mainly related to geomorphological variables such as regional coastal elevation, coastal slope and the rate of shoreline change, in addition to environmental and socioeconomic factors.

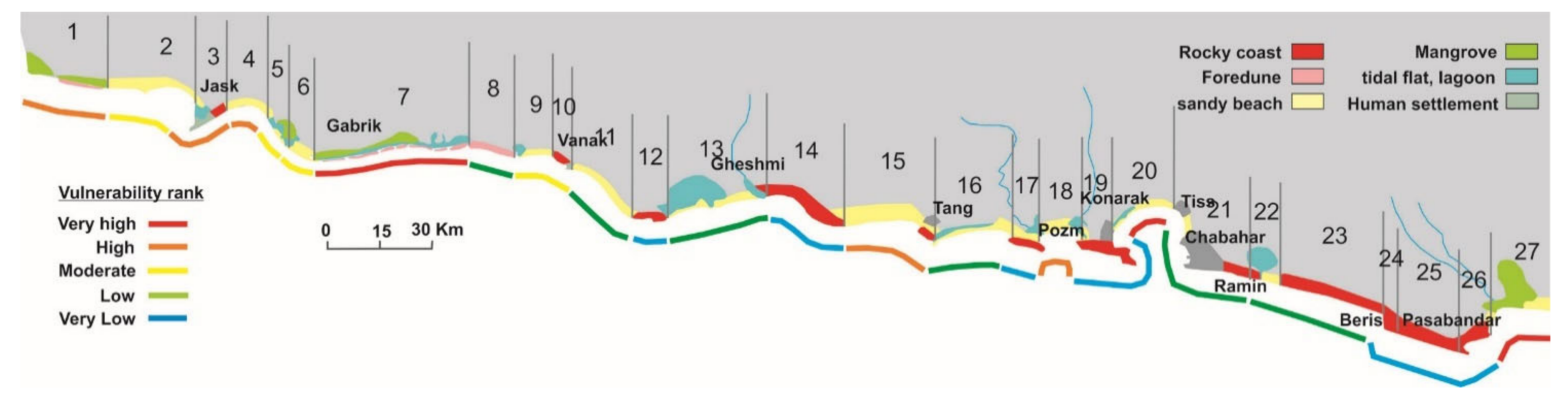

Figure 10. Coastal segments and overall risk rating of the Iranian coast of Makran based on CVI calculations.

Table 3. Coastal vulnerability to sea level rise based on the risk variables.

\begin{tabular}{|c|c|c|c|c|c|c|c|c|}
\hline \multirow[b]{2}{*}{$\begin{array}{c}\text { Coastal } \\
\text { Segment No. }\end{array}$} & \multicolumn{8}{|c|}{ Risk Variables } \\
\hline & Coastal Slope & $\begin{array}{c}\text { Regional } \\
\text { Coastal } \\
\text { Elevation }\end{array}$ & $\begin{array}{c}\text { Mean Tidal } \\
\text { Range }\end{array}$ & $\begin{array}{c}\text { Mean } \\
\text { Significant } \\
\text { Wave Height }\end{array}$ & $\begin{array}{c}\text { Rate of } \\
\text { Shoreline } \\
\text { Change }\end{array}$ & $\begin{array}{l}\text { Relative Sea } \\
\text { Level Change }\end{array}$ & $\begin{array}{c}\text { Environmental } \\
\text { Sensitivity }\end{array}$ & $\begin{array}{l}\text { Socioeconomic } \\
\text { Sensibility }\end{array}$ \\
\hline 1 & 4 & 4 & 3 & 3 & 3 & 2 & 5 & 2 \\
\hline 2 & 5 & 4 & 3 & 3 & 3 & 2 & 3 & 2 \\
\hline 3 & 3 & 3 & 3 & 3 & 5 & 2 & 3 & 5 \\
\hline 4 & 4 & 3 & 3 & 3 & 3 & 2 & 4 & 2 \\
\hline 5 & 2 & 4 & 3 & 3 & 3 & 2 & 5 & 2 \\
\hline 6 & 2 & 4 & 3 & 3 & 3 & 2 & 4 & 2 \\
\hline 7 & 4 & 4 & 3 & 3 & 5 & 2 & 5 & 2 \\
\hline 8 & 4 & 4 & 3 & 3 & 3 & 2 & 3 & 1 \\
\hline 9 & 4 & 4 & 3 & 3 & 3 & 2 & 4 & 2 \\
\hline 10 & 4 & 3 & 3 & 3 & 3 & 2 & 3 & 3 \\
\hline 11 & 3 & 3 & 3 & 3 & 3 & 2 & 3 & 1 \\
\hline 12 & 3 & 1 & 3 & 3 & 3 & 2 & 1 & 3 \\
\hline 13 & 3 & 3 & 3 & 3 & 3 & 2 & 5 & 1 \\
\hline 14 & 3 & 1 & 3 & 3 & 3 & 2 & 1 & 2 \\
\hline 15 & 3 & 3 & 3 & 3 & 3 & 2 & 4 & 4 \\
\hline 16 & 3 & 3 & 3 & 3 & 3 & 2 & 4 & 1 \\
\hline 17 & 3 & 1 & 3 & 3 & 3 & 2 & 1 & 2 \\
\hline 18 & 5 & 3 & 3 & 3 & 3 & 2 & 4 & 4 \\
\hline 19 & 3 & 1 & 3 & 3 & 3 & 2 & 1 & 4 \\
\hline 20 & 5 & 3 & 3 & 3 & 3 & 2 & 4 & 5 \\
\hline 21 & 3 & 1 & 3 & 3 & 3 & 2 & 2 & 5 \\
\hline 22 & 3 & 2 & 3 & 3 & 3 & 2 & 3 & 2 \\
\hline 23 & 3 & 2 & 3 & 3 & 3 & 2 & 2 & 2 \\
\hline 24 & 3 & 1 & 3 & 3 & 3 & 2 & 1 & 4 \\
\hline 25 & 3 & 1 & 3 & 3 & 3 & 2 & 1 & 2 \\
\hline 26 & 3 & 1 & 3 & 3 & 3 & 2 & 1 & 4 \\
\hline 27 & 5 & 4 & 3 & 3 & 3 & 2 & 5 & 5 \\
\hline
\end{tabular}


Table 4. CVI values and rankings for 27 coastal segments of the Iranian coast of Makran.

\begin{tabular}{|c|c|c|}
\hline Coastal Section No. & CVI & CVI Ranking \\
\hline 1 & 32.9 & High \\
\hline 2 & 28.5 & Moderate \\
\hline 3 & 39.0 & High \\
\hline 4 & 36.0 & High \\
\hline 5 & 23.2 & Moderate \\
\hline 6 & 20.8 & Moderate \\
\hline 7 & 42.4 & Very High \\
\hline 8 & 18.0 & Low \\
\hline 9 & 29.4 & Moderate \\
\hline 10 & 27.0 & Moderate \\
\hline 11 & 13.5 & low \\
\hline 12 & 7.8 & Very low \\
\hline 13 & 17.4 & Low \\
\hline 14 & 6.4 & Very low \\
\hline 15 & 31.2 & High \\
\hline 16 & 15.6 & Low \\
\hline 17 & 6.4 & Very low \\
\hline 18 & 40.2 & High \\
\hline 19 & 9.0 & Very low \\
\hline 20 & 45.0 & Very High \\
\hline 21 & 14.2 & Low \\
\hline 22 & 15.6 & Low \\
\hline 23 & 12.7 & Low \\
\hline 24 & 9.0 & Very low \\
\hline 25 & 6.4 & Very low \\
\hline 26 & 9.0 & Very low \\
\hline 27 & 52.0 & Very High \\
\hline
\end{tabular}

\section{Discussion}

Concerns about the devastating effects of global climate change, in particular SLR, on coastal areas have increased in the international scientific community, as well as decision makers and the public. CVI determination is one of the most widely applied and popular methods to evaluate the vulnerability of coastal areas to SLR and other hazards. The CVI method was originally introduced by Gornitz [13], taking into account physical variables as the main risk factors for vulnerability analysis. In later studies, population density was also added as a socioeconomic risk factor. Successive studies have modified the main risk factors in line with local objectives. Nonetheless, the main approaches of CVI remain generally unchanged. The CVI method is a powerful tool for coastal zone management on a wide scale; it highlights coastal hazard hotspots to SLR and other threats in order to develop national and regional mitigation plans. The methodology used in this study was based on the CVI approach described by Thieler and Hammer-Klose [35,36]. The risk variables were adapted to the physical, environmental and socioeconomic characteristics of the Makran coast. In order to generate an applied CVI map, the coast was divided into 27 segments based on geomorphological, environmental and socioeconomic properties. We determined eight risk variables, including six physical variables-coastal slope, regional coastal elevation, rate of shoreline change, significant wave height, relative sea level rise and mean tidal range- in addition to environmental and socioeconomic sensitivity factors.

The CVI rating of all coastal segments is presented in Table 4 and Figure 10. Three coastal sections $(7,20$ and 27) showed CVI ratings higher than 40 and were deemed very highly vulnerable to SLR. Two of these areas comprised environmentally protected lagoons and mangrove forests. In natural conditions, sandy barrier islands, sand spits and foredunes up to $14 \mathrm{~m}$ high protect the lagoons and tidal flats from extreme wave impacts. Constructions of coastal infrastructure and dams on hinterland rivers have interrupted sediment supply to the coast, especially in segment 7 , where clastic landforms were clearly 
eroded in recent decades (Figure 7). Segment 20 comprises sandy beaches inside Chabahar Bay. This section of the coast hosts extensive industrial activities, including a desalination plant and port facilities. Tidal creeks on the eastern side of the bay and coral formations in the shallow water are very sensitive to SLR, erosion and pollution. Five segments of the coast $(1,3,4,15$ and 18$)$, with CVI ratings between 30 and 40 were deemed highly vulnerable. These coastal segments mainly consist of low-lying sandy beaches that are connected to seasonal rivers and tidal creeks-points at which sediment supply is injected into the coastal system. Many local inhabitants live near to these beaches in order to use available fresh water and have access to the fishing harbors.

Five other coastal sections $(2,5,6,9,10)$ with CVI ratings between 20 and 30 were deemed moderately vulnerable. These mainly consist of rocky platforms or stable foredunes less than $10 \mathrm{~m}$ high. These landforms seem to have low vulnerability to lower SLR scenarios, but may be inundated in case of extreme SLR and/or extreme high-energy events such as severe storms or tsunamis. For five segments $(11,13,16,21$ and 23), the CVI rates were between 10 and 20, which is considered low vulnerability. Seven segments $(12,14,17,19$, 24, 25 and 26) manifested low vulnerability with a CVI rate $<10$. These segments were primarily high rocky coasts or foredune-protected coastal plains higher than $10 \mathrm{~m}$. At the time of this study, human populations are almost absent from these parts of the coast.

Our results show that the western part of the Iranian coast of Makran is particularly vulnerable to SLR. Two recent studies investigated coastal vulnerability along the Strait of Horomz and concluded that the western part of the coast of Makran was highly vulnerable to different climate change scenarios. The western section of the coast is generally lower than the eastern part and consists of environmentally important tidal flats and creeks. The geomorphology and environments of this area are inherently more sensitive. This could be worsened by the building of dams and new coastal infrastructure that may interrupt natural sediment dynamics and pathways.

This study highlighted SLR as a direct corollary of global climate change. However, other hazards, such as increasing storm frequency and intensity, saltwater intrusion, rising temperatures, changes in precipitation patterns, oil spills and other industrial pollutants, pose significant threats to the Makran coast. We believe that this study could be used to highlight highly vulnerable hazard hotspots on the Makran coast. It could also help decision makers protect communities and resources.

\section{Conclusions}

A Coastal Vulnerability Index to sea level rise was developed for 27 coastal segments of the Iranian coast of Makran based on eight risk variables, including coastal slope, regional coastal elevation, rate of shoreline change, significant wave height, relative sea level rise, mean tidal range, environmental sensitivity and socioeconomic sensitivity. The vulnerability to each risk was denoted using a 5-category scale. The vulnerability index demonstrated that three zones $(\sim 12.2 \%)$ of the Iranian Makran coast were extremely vulnerable to SLR, mainly parts of the mangrove forest and environmentally protected areas of the coast within these areas. Inundation and erosion will be a serious threat to these zones in the near future. Three coastal zones ( 20.5\%), including sandy beaches, were highly vulnerable. Twelve coastal segments $(\sim 50 \%)$, mainly consisting of rocky shores, showed low or very low levels of vulnerability to SLR. Population centers and infrastructure around Chabahar and Pozm bays were ranked as very highly to moderately vulnerable to SLR. Given that physical risk variables, such as tidal range, significant wave height and relative sea level changes, are generally constant along the studied coast, variations in coastal vulnerability to SLR are mainly controlled by geomorphological, environmental and socioeconomic factors. Considering a wide range of risk factors, this study adopted the CVI method as a tool to evaluate the vulnerability of the SE coast of Iran to SLR. It aimed to furnish decision makers and local inhabitants with quantified data to better plan for the negative effects of global climate change and sea level rise on coastal societies and environments. 
Author Contributions: Conceptualization, E.G. and M.S.-H.; methodology, E.G. and M.S.-H.; fieldwork, E.G. and M.S.-H. software, E.G. and M.S.-H.; validation, E.G., M.S.-H. and N.M.; resources, E.G.; data curation, E.G., M.S.-H. and N.M.; original draft preparation, E.G., M.S.-H. and N.M.; review and editing, E.G., M.S.-H. and N.M.; visualization, M.S.-H.; supervision, E.G.; project administration, E.G.; funding acquisition, E.G. All authors have read and agreed to the published version of the manuscript.

Funding: This research received no external funding.

Institutional Review Board Statement: Not applicable.

Informed Consent Statement: Not applicable.

Data Availability Statement: Data is available in this manuscript and raw data could be available on request.

Conflicts of Interest: The authors declare no conflict of interest.

\section{References}

1. De Pippo, T.; Donadio, C.; Pennetta, M.; Petrosino, C.; Terlizzi, F.; Valente, A. Coastal hazard assessment and mapping in Northern Campania, Italy. Geomorphology 2008, 97, 451-466. [CrossRef]

2. Kunte, P.D.; Jauhari, N.; Mehrotra, U.; Kotha, M.; Hursthouse, A.; Gagnon, A.S. Multi-hazards coastal vulnerability assessment of Goa, India, using geospatial techniques. Ocean Coast. Manag. 2014, 95, 264-281. [CrossRef]

3. Benassai, G.; Di Paola, G.; Aucelli, P.P.C. Coastal risk assessment of a micro-tidal littoral plain in response to sea level rise. Ocean Coast. Manag. 2015, 104, 22-35. [CrossRef]

4. Pendleton, E.A.; Thieler, E.R.; Williams, S.J. Coastal Vulnerability Assessment of Golden Gate National Recreation Area to Sea-Level Rise; Open-File Report 2005-1058; USGS: Denver, CO, USA, 2005.

5. Pendleton, E.; Barras, J.; Williams, S.; Twichell, D. Coastal Vulnerability Assessment of the Northern Gulf of Mexico to Sea-Level Rise and Coastal Change; Open-File Report 2010-1146; USGS: Denver, CO, USA, 2010.

6. Field, C.B.; Barros, V.R.; Dokken, D.J.; Mach, K.J.; Mastrandrea, M.D.; Bilir, T.E.; Chatterjee, M.; Ebi, K.L.; Estrada, Y.O.; Genova, R.C.; et al. Intergovernmental Panel on Climate Change. Climate Change, Impacts, Adaptation, and Vulnerability. Part A: Global and Sectoral Aspects. Contribution of Working Group II to the Fifth Assessment Report of the Intergovernmental Panel on Climate Change; Cambridge University Press: Cambridge, UK; New York, NY, USA, 2014; p. 1132.

7. Meehl, G.A.; Washington, W.M.; Collins, W.D.; Arblaster, J.M.; Hu, A.; Buja, L.E.; Strand, W.G.; Teng, H. How much more global warming and sea level rise? Science 2005, 307, 1769-1772. [CrossRef] [PubMed]

8. Evan, A.T.; Camargo, S.J. A climatology of Arabian Sea cyclonic storms. J. Clim. 2011, 24, 140-158. [CrossRef]

9. Murakami, H.; Vecchi, G.A.; Underwood, S. Increasing frequency of extremely severe cyclonic storms over the Arabian Sea. Nat. Clim. Chang. 2017, 7, 885-889. [CrossRef]

10. Dwarakish, G.S.; Vinay, S.A.; Natesan, U.; Asano, T.; Kakinuma, T.; Venkataramana, K.; Pai, B.J.; Babita, M.K. Coastal vulnerability assessment of the future sea level rise in Udupi coastal zone of Karnataka state, west coast of Indian Ocean. Coast. Manag. 2009, 52, 467-478.

11. Gornitz, V.; Daniels, R.C.; White, T.W.; Birdwell, K.R. The development of a coastal risk assessment database: Vulnerability to sea-level rise in the US southeast. J. Coast. Res. 1994, 12, 327-338.

12. Thieler, E.R.; Hammer-Klose, E.S. National Assessment of Coastal Vulnerability to Sea-Level Rise: Preliminary Results for the US Atlantic Coast; United States Geological Survey (USGS): Woods Hole, MA, USA, 1999.

13. Gornitz, V. Global coastal hazards from future sea level rise. Glob. Planet. Chang. 1991, 3, 379-398. [CrossRef]

14. Addo, K. Assessing coastal vulnerability index to climate change: The case of Accra e Ghana, Proceedings 12th International Coastal Symposium (Plymouth, England). J. Coast. Res. Spec. Issue 2013, 65, 1892-1897. [CrossRef]

15. Koroglu, A.; Ranasinghe, R.; Jimenez, J.A.; Dastgheib, A. Comparison of Coastal Vulnerability Index applications for Barcelona Province. Ocean Coast. Manag. 2019, 178, 104799. [CrossRef]

16. Normand, R.; Simpson, G.; Herman, F.; Biswas, R.H.; Bahroudi, A.; Schneider, B. Dating and morpho-stratigraphy of uplifted marine terraces in the Makran subduction zone (Iran). Earth Surf. Dyn. 2019, 7, 321-344. [CrossRef]

17. Reyss, J.L.; Pirazzoli, P.A.; Haghipour, A.; Hatté, C.; Fontugne, M. Quaternary marine terraces and tectonic uplift rates on the south coast of Iran. Geol. Soc. Lond. Spéc. Publ. 1999, 146, 225-237. [CrossRef]

18. Normand, R.; Simpson, G.; Bahroudi, A. Pleistocene Coastal Evolution in the Makran Subduction Zone. Front. Earth Sci. 2019, 7, 186. [CrossRef]

19. Okal, E.A.; Synolakis, C.E. Far-field tsunami hazard from mega-thrust earthquakes in the Indian Ocean. Geophys. J. Int. 2008, 172, 995-1015. [CrossRef]

20. Dibajnia, M.; Soltanpour, M.; Nairn, R.; Allahyar, M. Indian Ocean Tropical Cyclones and Climate Change; Charabi, Y., Ed.; Springer: Berlin/Heidelberg, Germany, 2010; 373p. 
21. Fritz, H.M.; Blount, C.D.; Albusaidi, F.B.; Al-Harthy, A.H.M. Cyclone Gonu storm surge in Oman. Estuarine Coast. Shelf Sci. 2010, 86, 102-106. [CrossRef]

22. Goharnejad, H.; Shamsai, A.; Hosseini, S.A. Vulnerability assessment of southern coastal areas of Iran to sea level rise: Evaluation of climate change impact. Oceanologia 2013, 55, 611-637. [CrossRef]

23. Mafi-Gholami, D.; Zenner, E.K.; Jaafari, A.; Bakhtyari, H.R.R.; Bui, D.T. Multi-hazards vulnerability assessment of southern coasts of Iran. J. Environ. Manag. 2019, 252, 109628. [CrossRef] [PubMed]

24. Hadipour, V.; Vafaie, F.; Kerle, N. An indicator-based approach to assess social vulnerability of coastal areas to sea-level rise and flooding: A case study of Bandar Abbas city, Iran. Ocean Coast. Manag. 2019, 188, 105077. [CrossRef]

25. Regard, V.; Bellier, O.; Thomas, J.-C.; Bourlès, D.; Bonnet, S.; Abbassi, M.R.; Braucher, R.; Mercier, J.; Shabanian, E.; Soleymani, S.; et al. Cumulative right-lateral fault slip rate across the Zagros-Makran transfer zone: Role of the Minab-Zendan fault system in accommodating Arabia-Eurasia convergence in southeast Iran. Geophys. J. Int. 2005, 162, 177-203. [CrossRef]

26. Prins, M.; Postma, G.; Weltje, G. Controls on terrigenous sediment supply to the Arabian Sea during the late Quaternary: The Makran continental slope. Mar. Geol. 2000, 169, 351-371. [CrossRef]

27. Haghipour, N.; Burg, J.-P.; Ivy-Ochs, S.; Hajdas, I.; Kubik, P.; Christl, M. Correlation of fluvial terraces and temporal steady-state incision on the onshore Makran accretionary wedge in southeastern Iran: Insight from channel profiles and 10Be exposure dating of strath terraces. GSA Bull. 2014, 127, 560-583. [CrossRef]

28. Shah-Hosseini, M.; Ghanavati, E.; Morhange, C.; Beni, A.N.; Lahijani, H.A.; Hamzeh, M.A. The evolution of Chabahar beach ridge system in SE Iran in response to Holocene relative sea level changes. Geomorphology 2018, 318, 139-147. [CrossRef]

29. Grando, G.; McClay, K. Morphotectonics domains and structural styles in the Makran accretionary prism, offshore Iran. Sediment. Geol. 2007, 196, 157-179. [CrossRef]

30. Heidarzadeh, M.; Pirooz, M.D.; Zaker, N.H.; Yalciner, A.C.; Mokhtari, M.; Esmaeily, A. Historical tsunami in the Makran Subduction Zone off the southern coasts of Iran and Pakistan and results of numerical modeling. Ocean Eng. 2008, 35, 774-786. [CrossRef]

31. Shah-Hosseini, M.; Morhange, C.; Beni, A.N.; Marriner, N.; Lahijani, H.; Hamzeh, M.A.; Sabatier, F. Coastal boulders as evidence for high-energy waves on the Iranian coast of Makran. Mar. Geol. 2011, 290, 17-28. [CrossRef]

32. Page, W.D.; Alt, J.N.; Cluff, L.S.; Plafker, G. Evidence for the recurrence of large-magnitude earthquakes along the Makran coast of Iran and Pakistan. Tectonophysics 1979, 52, 533-547. [CrossRef]

33. Von Rad, U.; Schaaf, M.; Michels, K.H.; Schulz, H.; Berger, W.H.; Sirocko, F. A 5000-year record of climatic change in varved sediments from the oxygen minimum zone off Pakistan, NE Arabian Sea. Quat. Res. 1999, 51, 39-53. [CrossRef]

34. Von Rad, U.; Schulz, H.; Riech, V.; den Dulk, M.; Berner, U.; Sirocko, F. Multiple monsoon-controlled breakdown of oxy-genminimum conditions during the past 30,000 years documented in laminated sediments off Pakistan. Palaeogeogr. Palaeoclimatol. Palaeoecol. 1999, 152, 129-161. [CrossRef]

35. Shaw, J.; Taylor, R.B.; Forbes, D.L.; Ruz, M.-H.; Solomon, S. Sensitivity of the Canadian Coast to Sea-Level Rise; Geological Survey of Canada: Ottawa, ON, USA, 1998.

36. Thieler, E.R.; Hammer-Klose, E.S. National Assessment of Coastal Vulnerability to Sea-Level Rise: Preliminary Results for the U.S. Gulf of Mexico Coast; United States Geological Survey (USGS): Woods Hole, MA, USA, 2000.

37. Thieler, E.R.; Hammer-Klose, E.S. National Assessment of Coastal Vulnerability to Sea-Level Rise: Preliminary Results for the U.S. Pacific Coast; United States Geological Survey (USGS): Woods Hole, MA, USA, 2000.

38. Integrated Coastal Zone Management of Iran (ICZM). Ports and Maritime Organization of Iran. 2017. (In Persian). Available online: https: / / aquadocs.org/ (accessed on 1 March 2020).

39. Doukakis, E. Coastal vulnerability and risk parameters. Eur. Water 2005, 11, 3-7.

40. Gaki-Papanastassiou, K.; Karymbalis, E.; Poulos, S.E.; Seni, A.; Zouva, C. Coastal vulnerability assessment to sea-level rise based on geomorphological and oceanographical parameters: The case of Argolikos Gulf, Peloponnese, Greece. Hell. J. Geosci. 2010, 45, $109-121$.

41. Gorokhovich, Y.; Leiserowitz, A.; Dugan, D. Integrating coastal vulnerability and community-based subsistence resource mapping in Northwest Alaska. J. Coast. Res. 2014, 293, 158-169.

42. Lopez, R.M.; Ranasinghe, R.; Jiménez, J.A. A rapid, low-cost approach to coastal vulnerability assessment at a national level. J. Coast. Res 2016, 32, 932-945. [CrossRef]

43. Saket, A.; Etemad-Shahidi, A. Wave energy potential along the northern coasts of the Gulf of Oman, Iran. Renew. Energy 2012, 40, 90-97. [CrossRef]

44. Church, J.A.; White, N.J.; Hunter, J.R. Sea-level rise at tropical Pacific and Indian Ocean islands. Glob. Planet. Chang. 2006, 53, 155-168. [CrossRef]

45. Sweet, W.V.; Kopp, R.E.; Weaver, C.P.; Obeysekera, T.; Horton, R.M.; Thieler, E.R.; Zervas, C. Global and Regional Sea Level Rise Scenarios for the United States; NOAA Technical Report NOS CO-OPS 083; National Oceanic and Atmospheric Administration; National Ocean Service: Silver Spring, MD, USA, 2017; 75p.

46. Climate Change, the Scientific Basis. Contribution of Working Group I to the Third Assessment Report of the Intergovernmental Panel on Climate Change (TAR-IPCC); Cambridge University Press: Cambridge, UK, 2001.

47. Milne, G.A.; Gehrels, W.R.; Hughes, C.W.; Tamisiea, M.E. Identifying the causes of sea-level change. Nat. Geosci. 2009, 2, 471-478. [CrossRef] 
48. Gilman, E.; Ellison, J.; Jungblat, V.; Van Lavieren, H.; Wilson, L.; Areki, F.; Brighouse, G.; Bungitak, J.; Dus, E.; Henry, M.; et al. Adapting to Pacific Island mangrove responses to sea level rise and other climate change effects. Clim. Res. 2006, 32, 161-176. [CrossRef]

49. Kumar, T.S.; Mahendra, R.S.; Nayak, S.; Radhakrishnan, K.; Sahu, K.C. Coastal Vulnerability Assessment for Orissa State, East Coast of India. J. Coast. Res. 2010, 263, 523-534. [CrossRef]

50. McLaughlin, S.; Cooper, J.A.G. A multi-scale coastal vulnerability index: A tool for coastal managers? Environ. Hazards 2010, 9 , 233-248. [CrossRef]

51. Di Paola, G.; Iglesias, J.; Rodríguez, G.; Benassai, G.; Aucelli, P.P.C.; Pappone, G. Estimating Coastal Vulnerability in a Meso-Tidal Beach by Means of Quantitative and Semi-Quantitative Methodologies. J. Coast. Res. 2011, 61, 303-308. [CrossRef]

52. Gharibreza, M. Evolutionary trend of paleoshorelines in the Coastal Makran zone (Southeast Iran) since the mid-Holocene. Quat. Int. 2016, 392, 203-212. [CrossRef] 